IRA-International Journal of Management \& Social Sciences

ISSN 2455-2267; Vol.08, Issue 01 (July 2017)

Pg. no. 17-30

Institute of Research Advances

http://research-advances.org/index.php/RAJMSS

\title{
Effect of Organizational Commitment, Competence and Good Governance on Employees Performance and Quality Asset Management
}

\author{
Hendra Gunawan', Murdifin Haming ${ }^{2}$, Junaiddin Zakaria ${ }^{3}$, Asdar Djamareng ${ }^{4}$ \\ ${ }^{1}$ Doctoral Student in the Faculty of Economics, Muslim University of Indonesia, Indonesia. \\ ${ }^{2.3,4}$ Faculty of Economics, Muslim University of Indonesia, Indonesia.
}

Type of Review: Peer Reviewed.

DOI: http://dx.doi.org/10.21013/jmss.v8.n1.p3

\begin{abstract}
How to cite this paper:
Gunawan, H., Haming, M., Zakaria, J., \& Djamareng, A. (2017). Effect of Organizational Commitment, Competence and Good Governance on Employees Performance and Quality Asset Management. IRA-International Journal of Management \& Social Sciences (ISSN 2455-2267), 8(1), 17-30. doi:http://dx.doi.org/10.21013/jmss.v8.n1.p3
\end{abstract}

(C) Institute of Research Advances.

\section{(cc) BY-NC}

This work is licensed under a Creative Commons Attribution-Non Commercial 4.0 International License subject to proper citation to the publication source of the work.

Disclaimer: The scholarly papers as reviewed and published by the Institute of Research Advances (IRA) are the views and opinions of their respective authors and are not the views or opinions of the IRA. The IRA disclaims of any harm or loss caused due to the published content to any party.

Institute of Research Advances is an institutional publisher member of Publishers Inter Linking Association Inc. (PILA-CrossRef), USA. The institute is an institutional signatory to the Budapest Open Access Initiative, Hungary advocating the open access of scientific and scholarly knowledge. The Institute is a registered content provider under Open Access Initiative Protocol for Metadata Harvesting (OAI-PMH).

The journal is indexed \& included in WorldCat Discovery Service (USA), CrossRef Metadata Search (USA), WorldCat (USA), OCLC (USA), Open J-Gate (India), EZB (Germany) Scilit (Switzerland), Airiti (China), Bielefeld Academic Search Engine (BASE) of Bielefeld University, Germany, PKP Index of Simon Fraser University, Canada. 


\begin{abstract}
This research aims to examine and analyze the influence of organizational commitment, competence and governance to employee performance and quality asset management at the regional Work Units (SKPD) of The Makassar city government. This research is an explanatory research, by observing cross-section a on the 203 civil servants who work in the 64 Regional Work Units (SKPD SKPD) Government of Makassar, using total sampling as sampling technique. Analysis of Structural Equation Model (SEM) through Analysis of Moment Structures (AMOS) Ver. 18 is used as a data analysis tool.

Hypothesis testing results provide evidence that organizational commitment, competence and good governance has a positive and significant effect on employee performance. Organizational commitments have a negative and significant effect on the quality of asset management. The different results shown on the competence, good governance and employee performance are positive and significant effect on the Quality asset management for local Governments. Organizational commitment and competence indirectly significant effect on the quality asset management for local Governments: The mediating role of employee performance. On the other mediator variable testing, good governance indirectly has a significant effect on the quality of asset management: The mediating role of employee performance.
\end{abstract}

Keywords: organizational commitment, competence, good governance, employee performance, quality asset management for local governments

\title{
Introduction
}

The financial statements of local government is a form of government responsibility to the interested area which include a wide range of jobs in financial need, including a component that is reflected in the balance sheet assets in the region where every year a report made after the implementation of the budget. Preparation of financial statements made after the financial statements of regional work units (SKPD) with restrictions within two months after the fiscal year ends. The report includes the statement of cash flows, budget realization report, notes to the financial statements and balance sheets of regional work units (SKPD). The financial report is a follow-up package of laws on state finances.

This is a new phenomenon for local governments in managing their finances and assets in order to become better, although in a short time much less convinced that the financial management and appropriate asset package these laws implemented. This is because the local government has not been able to do financial reporting in accordance with applicable regulations. Quantitatively, this is reflected by the number of local governments that receive the best opinions or views, Unqualified Opinion (WTP) of the Supreme Audit Board (BPK) on the implementation of the financial statements, in which the result is not yet meet the expectations of society. So that every government in the area can obtain the opinions the best, the opinions or the opinions shall include unqualified Opinion (WTP), qualified opinion (WDP), adverse and disclaimer opinion.

Local assets, it must be managed properly so that it will materialize goods management areas that are transparent, efficient, accountability and certainty value that can function in accordance with the duties and functions of the local government. Asset Management is the asset management define well in terms of measuring the value of assets in monetary terms and employing the minimum amount of expenditure on its management (Siregar, 2004: 517).

The phenomenon to be observed is in the implementation, asset management or property in the area of Makassar city government scope cannot be performed optimally. This is reflected in the findings of the Indonesian supreme audit board (BPK), both testing aspects of regional asset management as part of the audit of financial statements of the government of Makassar as a whole, as well as through a special audit of asset management area. Until now, some of the findings that cannot be acted upon, even though the whole range of SKPD related Makassar city government have been proactive in efforts to resolve the findings of BPK audit results. 
Problems that hamper the opinion have not been obtained Unqualified Opinion (WTP), which is obtained from the Indonesian supreme audit board (BPK). Special to the financial statements of local government (LKPD), is still associated with cash management, inventory, permanent and non-permanent investments, as well as a majority due to the management of fixed assets that have not been accountability. Problems fixed assets of local government in general is related to the local-Owned Property (BMD) is not recorded, local-Owned Property that does not exist it is still noted, local-Owned Property is recorded but not supported by the documents of ownership. One major cause of this problem is still a lack of understanding of local property management officer, in this case the Board of Goods, Goods Storage, Structural immediate supervisor Goods Board, and even served as a leadership SKPD Users goods.

Asset management policy is the discussion of strategies of an organization (both private and government) in a particular area, namely asset management. Therefore, the policy is appropriate based on the policies and objectives of the organization are consistent with employment policy and objective performance of the government and can respond to the needs and expectations of society. An integrated approach to asset management is a concept that is increasingly evident that the organization in this case is the Office for Management of Regional Revenue, Finance and Assets Makassar (BPKA) should follow the principle of sustainability for the asset manager is not just about extending the lifespan of the asset and ensure that these assets operate efficiently and economically. But the principle is more focused on the consideration of how the organization produces employees who have competence in asset management. Area property management officer, especially the management and storage of goods SKPD, it is very important to conduct training on an ongoing basis in an effort to increase the understanding getting better and better, and to equip management / storage of goods. Challenges ahead in asset management that every government organization makes a commitment to quality considerations asset management so that the organization can consider a sustainable when it will create and trigger a policy objective

Some empirical evidence showing that an organizational commitment significant effect on the asset management area, so that the better management of assets is applied then the resulting financial statements to be more qualified (Rahmawati Halim, 2012). Optimization of quality asset management for local Governments has a positive and significant effect on the quality of government financial reports of Makassar city (John Gamara Tangke, Halim and Tangke, 2015).

Organizational commitment related to the property management area so that coordination to achieve common goals in the orderly administration of the same item needed perception is also integrally. Then the constraints of human resources is central, where the conditions of personnel resources in every field in the Office for Management of Regional Revenue, Finance and Assets is still very limited and insufficient work necessary (Hasfi, \& Martoyo, 2013). Asset management quality is affected by the implementation of asset management, asset management reporting accountability and quality of human resources (competence) (Pekei, Hadiwidjojo \& Djumahir, 2014).

\section{Literature review}

\section{Organizational commitment}

Organizational commitment, namely a commitment roommates rise not just to be passive loyalty, but to participate of active relations with organizations (Gimbart 2008: 520). Organizational commitment has an embodiment of the individual loyalty to the organizations. Three characteristics are used as guidance in implementing organizational commitment, namely: (1) strong beliefs about the organization. (2) To defend themselves in order to permanent a member of the organization; and (3) endeavour as part of the member organizations (Ibrahim, 2008: 525). Organizational commitment includes three components, namely: (1) an affective commitment is associated with emotional commitment, identification, and involvement in the organization. Individuals with component, affective a high it will not break away from the organization because of the encouragement desire to remain bound to the organization. The key to this commitment is the employees stay because they want to, (2) normative commitments are individual beliefs about the obligation to contribute to the organization. Individuals must do the work to achieve the goals of an organization, have term employees stay Because they have to, and (3) continuance commitment is a commitment to rational formed on the basis of cost-benefit considerations facing individuals when faced with a decision to remain in the organization or about to come out of the organization (employees stay because they feel they ought to).

Empirical evidence shows that organizational commitment is a significant effect on the individuals' performance (Sri Trisnaningsih 2007; Natalia Dewinda Putri, 2010). The findings were obtained rebuttal, that the commitment 
the organization does not affect the individual performance (Nurul Azizah, 2012; Fifien Dhesta Listiyana, 2015). The construct of organizational commitment to develop the organizational commitment questionnaire (OCQ) (Allen \& Meyer, 2009: 18) that set the organizational commitment of three components: affective commitment, normative commitment and continuance commitment.

\section{Competence}

The concept of competence is very important role in the governance. Because of the success of an organization becomes an important work in realizing the objectives to be achieved. Context of managerial competence is an important baseline characteristic in a person who is predicted to realize the success of the work. Competence can be understood as a factor which distinguishes a person able to show optimal performance with someone who is not able to perform optimally. Competence is a collection of potentials that dynamically show the intellectual capacity, mental attitude and the quality of one's social capabilities (David McClelland, in Martin, 2002: 151).

Competence is an adequacy for the task or possession of required knowledge, skills and abilities (Huston and Robert, 1972). The studies of competence in the context of the field of asset management performance are basically understood as an employee capability in handling and provide decision-making related to the profession in the field of asset management / goods. Because the notion of competence is equated with asset management competence, as executor in finance that understand and have a working principle in developing capabilities on the basis of motives, talents, self-concepts, knowledge and skills in financial management. Competencies are the areas of knowledge, abilities and skills that increase of an individual's effectiveness in dealing with the World (Cohen, 2010:173).

Competence becomes an important part of the success of the performance-based asset management in realizing the objectives of the organization. Competence comes from the competent who means being able to commensurate with the word ability or ability to do a task or profession that was involved. This competency relates to the potential of the individual to behave and act to deal with asset management activities / finances corresponding objectives to be achieved (Walker, 2007: 77). Another assessment of an organization's success lies in teamwork.

The working team became one of the defining aspect of the organization is able to develop and progress. Competence of the management of assets viewed from the orientation of quality is reflected in five aspects: insight knowledge, skills, expertise, experience the concept of self, mastery of work based on talent and motive. Quality orientation competence of the management of goods / assets can be judged from a working knowledge that is understood in accordance with the level of education you have, the skills of a variety of educational and training programs that followed, the experience of working life traversed and mastery of work based on persistence owned (Harry, 2011: 95).

The build competence elements are a job knowledge, skills, experience and attitude. The importance of competence for the management of goods / assets viewed prospectively regarding competence as a science and an art that is highly considered in the application of managerial organization. Competence is a core of self-assessment that the board of the goods / assets there is great potential to be developed and promoted in accordance with their competence development.

The results of previous studies provide evidence that the level of competence has a significant effect on the individual performance (Goeslow Vanila, 2005; Stephen William, 2005; Thamrin, 2007; Surhatiningsih, 2008;Yoseph, 2009; Azis Rachman, 2012; Maturidi, 2014; Meynalti Handhayani, 2015). Constructs of Competency has extend to competency-based questionnaire (Spencer and Spencer, 1993), which includes; Motive, self-concept and knowledge.

\section{Good Governance}

Good Governance is the system by the organizations are directed and controlled. The corporate governance structure specifies the distribution of rights and responsibilities among different of participants in the organization, and spells out the rules and procedures for making decisions and corporate affairs. By doing this, it also provides the structure through the organization objectives are set and the means of Attaining Reviews those objectives and monitoring performance (The organization for economic cooperation and development, OECD, 2010:5).

Good governance is applied in an organization's internal control system is intended to do the settings related to the duties, rights and obligations of activities to achieve the goals obtained and evaluated for organizations survival in 
good governance. Governance that is good to have five different main objectives, namely: (1) protect the rights and interests of the leadership, (2) protect the rights and interests of subordinates, (3) increase the value of the organization, (4) improve the efficiency and effectiveness and (5) improve the quality of leadership and subordinate relationships (Thomas, 2008: 8). Financial Administrative governance is whole group of people working two or more based on the rationality of the policies, systems and procedures in the field of finance to achieve organizational goals (Finger and Pécoud, 2003).

In the administration of public Finance context, governance is defined as a business that is processed from cooperative activities that need each other to achieve common goals in the field of finance, on that basis, then created an activity that involves people working together in the interests arranging and fixing objectives to achieved as a manifestation of the results of activities and actions set (Siagian, 2004: 39). Good governance to be important in financial administration, in which the core of this science is orderly conduct of financial systems and working procedures (Rhodes, 1997). The essence of governance in public finances is "management" to achieve the financial performance of a series of processes involving individuals or groups are working together to realize the orderly finances.

This achievement is the result of the actions of the governance process-oriented Finance. Each activity needs good arrangement. The principle of good arrangement must involve participation, transparency, responsibility, accountability, consensus, efficiency and effective. Activity arrangement must involve the involvement of many people, is done in an open way, full responsibility in accepting and complete authority over the tasks assigned, accountability in implementation of activities, involving a collective agreement, efficient and effective use of time and the use of the budget (Adolf 2008).

Santoso (2008) states the terms creation of governance in government, private and public were based on good governance principles, namely: (1) Participation, se each of the regulatory and / or policy always involve an element of society, (2) Rule of law, there must be legal tools to crack down on offenders, ensure the protection of human rights, impartiality, apply to all citizens, (3) Transparency, a space of freedom to public information for people who need it based on the provisions of the wounded, (4) Responsiveness, public institutions must be able to respond to the needs of society, particularly those relating to basic needs and human rights,(5) the consensus, if there is a difference of fundamental importance in the community, solving problems should give priority to dialogue, (6) Equal rights, government must ensure that all parties without exception involved in the political process, (7) The effectiveness and efficiency, the government must be effective (valid) and efficient in producing outputs in the form of rules, policies, management of state finances, and (8) Accountability, an embodiment of the obligations of a government agency accountable for success and failure.

Sri Trisnaningsih (2007) provide evidence that the understanding of good governance no direct impact on individual performance. These results differ from the findings of other researchers, that good governance significant effect on the performance of local governments (Maturidi, 2014; Nur Azlina and Ira Amelia, 2014; Meynalti Handhayani, 2015). Measurement of governance include; participation, responsibility and accountability (Arthur, 2004: 155).

\section{Civil servants performance}

Civil servants performance is a matter of considerable interest to be discussed, because it would be very useful for law enforcement which is also beneficial for the benefit of individuals, communities, nations and countries. Basically, the Civil Service has a role and function as the implementing regulation laws that have been set by the government, functioning public service, and as a manager of administration. The role and function is already clear that the civil servants are very important.

However, not all employees are performing the role and function properly. To create good governance, professional and authoritative, influences the performance of civil servants that will either create an atmosphere that is safe and comfortable because the law actually made commander.

Indicators that can be used to assess compliance with the standard of work can be judged on the quality of work by the way: constantly analyzing data, preparing themselves in work, motivation self-development, adhere to labour standards set, neat, orderly, not avoid feedback, satisfied with the planning workable and strive to be the best. It can be concluded that performance measurement is an assessment activities attainment of certain targets that have the strategic objectives of the organization / institution in which the results of measurements of the gains are the basis 
for managing organizations / agencies to improve performance in the next period of performance is the responsibility of each individual to their work, help define performance expectations, seek a framework for supervisors and workers communicate with each other (Wibowo, 2007: 42).

Employee performance is the result of the quality and quantity of work achieved by an employee in performing their duties in accordance with the responsibilities given to him (Mangkunegara, 2000: 67). Performance as quality and quantity are always related to efficiency and effectiveness in accordance with loyalty in working for the achievement of the tasks, whether committed by individuals, groups and organizations (Schemerhorn, Hunt and Osborn, 2007: 91). If the job performance criteria have been defined, the next step in measuring performance is to collect information relating to such matters of a person during a certain period. By comparing these results against standards set for the time period in question, we will get level of an individual's performance.

The achievement of an organization's goals is only possible maximum work performance. Today many organizations in the development of human resources as a performance seek to make efforts from the achievement of organizational goals (Rivai, 2007: 12). Assessing the performance evaluation is not isolated, but relates to the ability to work and the level of achievement of appropriate working minimum service standards. This assessment is somewhat influenced by the quality of human resources in carrying out its duties and functions well. Thus, the individual performance increased if there is a match between the job and the ability to work in accordance with the contribution rate increased performance. Develop employee performance measurement constructs individual performance, the quantity, efficiency and effectiveness (Schemerhorn, Hunt and Osborn, 2007).

\section{Quality Asset Management}

Asset can be articulated as something tangible and intangible assets that have the potential to achieve the vision and mission. In another perspective, assets are defined as follows: asset is anything that has economic value that can be owned by an individual, company or government owned financial assessable. Assets or property owned by individuals e.g. a house, land, vehicles, and so on. The assets of the company e.g. office buildings, land companies, equipment and machinery, equipment and other property. Explicitly assets by economic standpoint is a good (thing) or for something (anything) that is owned by someone, organizations both private and government who have: (1) The economic value (economic value), (2) The commercial value (commercial value) and (3) the exchange rate (exchange value) asset Management is define good asset management in terms of measuring the value of properties (assets) in monetary terms and Employing the minimum amount of expenditure on its management (Siregar, 2004: 517).

Based on the management of physical assets, definitively Asset management is a science and an art to guide the wealth management that includes planning process needs assets, acquire, inventory, conduct legal audit, assess, operate, maintain or eliminate to transfer assets effectively and efficiently (Sugiama, 2013: 15). Based on some of these explanations, the asset management can be expressed as a systematic process that maintain, improve, and operate assets in a way that the most cost-effective through the creation, acquisition, operation, maintenance, rehabilitation, and elimination of assets related to (1) identify what is needed assets, (2) identify the need for funds, (3) acquire assets, (4) provide logistics and maintenance support system for assets, (5) remove or update an asset that effectively and efficiently to meet the objectives.

Management of local government assets can be divided into five stages of work which includes; an inventory of assets, legal audit, asset valuation, optimizing the utilization and development of SIMA (asset management information system), where five stages are interconnected and integrated with one another (Siregar, 2004: 518), through (1) Inventory assets, (2) Legal audit, (3) assets, (4) Optimization of assets, and (5) Supervision and control. The general objective is to do the asset management; (1) to minimize the whole life cost of assets, (2) the maximum profit, and (3) optimizing the utilization of assets (Siregar, 2004: 518-520).

Empirical evidence shows that the organizational commitment has a significant effect on the quality of local asset management (Rahmawati Halim, 2012). Organizational commitment through the asset management has a positive and significant effect on the quality of financial statements (John Gamara Tangke, Halim and Tangke, 2015). Other studies show that in addition to organizational commitment, (Syahruni Sukri, 2015) competence is reflected through human Quality Resources also has an important role in creating optimization Asset Management. Asset management quality is affected by the implementation of asset management, asset management reporting accountability and quality of human resources (competence) (Pekei, Hadiwidjojo \& Djumahir, 2014). The construct is used to analyze 
the quality of the management of assets, including assets Inventory, Asset Assessment and Optimization of assets as well as supervision and control (Siregar, 2004: 518-520).

Methods

This research is an explanatory research, by observing cross-section a on the 203 civil servants who work in the 64 Regional Work Units (SKPD SKPD) Makassar City Government. Analysis of Moment Structures (AMOS) Ver. 18 used in this study Results Characteristics of respondents have an important role in explaining the underlying characteristics of the respondents in this study.

Table 1. Characteristics of respondents

\begin{tabular}{|c|c|c|c|}
\hline \multicolumn{2}{|c|}{ Characteristics of respondents } & Frequency $(n=203)$ & Percent $(\%)$ \\
\hline \multirow{2}{*}{ Gender } & Male & 133 & 64 \\
& Female & 70 & 36 \\
\hline \multirow{4}{*}{ Age (years) } & $21-30$ & 32 & 15 \\
& $31-40$ & 106 & 53 \\
& $41-50$ & 20 & 10 \\
& $>50$ & 45 & 22 \\
\hline \multirow{3}{*}{ Education } & Senior High School & 57 & 28 \\
& Bachelor & 7 & 3 \\
& Bachelor honours & 90 & 45 \\
& Masters program & 49 & 24 \\
\hline \multirow{3}{*}{ Years of work experience } & $<5$ & 45 & 60 \\
& $5-10$ & 121 & 18 \\
\hline
\end{tabular}

The table shows that the frequency of respondents who most gender Male as many as 133 people or $64 \%$ and Female there are 70 people or 36\%. Most of the respondents attain the age of 31-40 years as many as 106 people or $53 \%$ of the level of educational generally educated honours bachelor as many as 90 people or $45 \%$ and Years of work experience between 5-10 years is 121 people or $60 \%$.

\section{Discussion}

\section{Linking of organizational commitment on civil servants performance}

Organizational commitment has a significant positive effect on civil servants performance with a value of $\alpha=0.000$ $>0.05$ with a coefficient 0.385 . This coefficient is positive. Thus, the results of the analysis show that the first hypothesis $\left(\mathrm{H}_{1}\right)$ research accepted. The results were significant, the better the organization's commitment owned by a civil servant, the civil servants performance will also increase. Thus the first hypothesis of the study is accepted. The findings are due to the asset management staff realized that affective commitment, normative and demonstrated sustainable asset management staff to do the job in the occupied areas of work to work optimally. Asset management staffs are required to commit to promote the organization where he works, to work in accordance with their duties and functions in order to achieve optimum performance. A civil servant has to show commitment in dealing with the dynamics of affective work to achieve optimal working results. Civil servants obligations that must be run as part of the task entrusted to asset management in Makassar City Government have implemented properly in order to achieve improved performance of asset management reports. The findings of this study are relevant to the claim that the organization's success can be seen from the achievement of progress, organizational discipline rules adhered to achieve organizational goals and the ability to maintain the achievements of the organization (Luthans, 2007: 66).

Achievement of performance within an organization needed a unified commitment. Relation to this discussion recognized that the management has implemented simultaneously is the fourth commitment. And this is the cause of significant work commitments to the achievement of employee performance (Allen and Meyer, 2009: 52). 
Organizational commitment is a significant effect on the performance of individuals (Sri Trisnaningsih 2007; Natalia Dewinda Putri, 2010). Rejected the findings of which proved that organizational commitment has no effect on the performance of individual (Nurul Azizah, 2012; Fifien Dhesta Listiyana, 2015).

\section{Linking of Competence on civil servants performance}

Competency have a positive and significant on Civil servants performance with a value of $\alpha=0,005>0.05$ and a coefficient by, 0368. Thus, the results of the analysis indicate that the second hypothesis $\left(\mathrm{H}_{2}\right)$ study the influence coefficient received this competency have a positive mathematical sign. It shows that the better the competency of asset management employee, then the employee's performance will increase. Thus the second hypothesis of the research is accepted. This study supports the statement of Barry (2011: 151), that the competence is ideal if supported by a strong motive, the nature of the dominant talents, develop self-concept, have extensive knowledge and skilled expertise. Each board of assets trying to evolve and move forward, regardless of the four elements are interrelated elements of knowledge appropriate educational background, skills in accordance with the level of expertise, self-concept appropriate work experience, talent accordance with the mastery of work and patterns according to the objectives to be achieved (Harijaya, 2010: 39). The results support the findings of previous investigators that competence significantly effect on individual performance (Goeslow Vanilla, 2005; Stephen William, 2005; Thamrin, 2007; Surhatiningsih, 2008; Joseph, 2009; Azis Rachman, 2012; Maturidi, 2014; Meynalti Handhayani, 2015)

\section{Linking of good governance on civil servants performance}

Good governance have a positive and significant effect on civil servants performance, effect of competence on civil servants performance with a value of $\alpha=0.028>0.05$ and a coefficient amounting to 0.224 . Thus, the results of the analysis indicate that the third hypothesis $\left(\mathrm{H}_{3}\right)$ studies. The effect of good governance acceptable coefficient is marked with a positive mathematical. This shows that the better knowledge of good governance owned asset management staff, the more it will improve the employee's performance.

Supports the result orientation theory presented by Aderson (2009: 155) that governance will embody results orientation achievement of high performance. This meant that the field of asset management needs to be based on the principles of participatory governance, responsibility and accountability to produce the work of asset management in accordance with the expected performance. The relevance of this theory supports the effect of governance in a significant effect on the performance of the asset management area in Makassar City Government. These studies support the notion that governance in the administration viewed as a paradigm of decision" which is understanding that in conducting a governance takes the decision making process in accordance approaches, systems and analysis to generate the governance representative suit organizational objectives, namely decision-making orderly financial . It supports the results of previous studies, that good governance significant effect on the performance of local governments (Maturidi, 2014; Nur Azlina and Ira Amelia, 2014; Meynalti Handhayani, 2015). Rejecting the good governance did not directly affect on the individual's performance (Sri Trisnaningsih, 2007).

\section{Linking of organizational commitment on quality asset management}

Organizational commitment have a negative and insignificant on the quality of asset management with a value of $\alpha$ $=0,914>0.05$ and a coefficient by $-0,012$. This means that organizational commitment does not significantly influence the quality of asset management. The coefficient of direct influence is marked with a negative mathematical. Thus, the results of the analysis showed that the fourth hypothesis $\left(\mathrm{H}_{4}\right)$ research rejected. This means that the higher organizational commitment owned by employees, tends to degrade the quality of asset management in the study. This means, organizational commitment does not directly improve the quality of asset management. Organizational commitments owned by employees not directly improve the quality of asset management, but organizational commitment indirect effect on the quality of asset management through employee performance. This suggests that the high organizational commitment to encourage improved performance of employees so that impact on increasing the quality of asset management.

The findings of this study confirm that institutional structures and resources of the managers of asset / goods to the institutional and resources will determine the success of the optimization. All the bureaucracy associated with asset management should have responsibility within the limits of its authority in order to spread fixed asset control, either through the mechanism of coordination and consolidation mechanism. Findings from this study differ with the statement, that a good system embodies good governance in the financial sector, that in managing the finances of the organization required a control system in accordance with the principles of good governance, so that errors, leakage 
and fraud can be minimized through the control system organization regular and orderly in accordance with the standards established (Dardton, 2009: 82). Support the findings of previous investigators found no significant organizational commitment to quality asset management (Alam M. Tahir, 2012; Meynalti Handhayani, 2015).

\section{Linking of competence on quality asset management}

Competence has a positive and significant effect on the quality of asset management for the value of $\alpha=0.025>$ 0.05 and a coefficient by 0352 . The coefficient is marked mathematical competence positive. Thus, the results of the analysis showed that the fifth hypothesis $\left(\mathrm{H}_{5}\right)$ received. This research shows that the better the competency of employees, the quality of asset management, the better. Representation of employee competence is reflected in the personality and passion to learn and pursue science. Consistent with the character and the response is certainly going to generate quality reports asset management.

The results of the study support the statement Stoner and Freedman. (2007: 64) that any individual who is not competent regardless of the orientation of quality. Orientation quality always put the best work of toil tirelessly. The more the challenge of working more and create opportunities to bring quality orientation. The theory of this quality orientation with regard to individual competence issues fall within the competence of employees. Then the findings of this study in line with the findings of previous studies that employee competence and a significant positive effect on the quality (Stephen William, 2005; Thamrin, 2007).

\section{Linking of good governance on quality asset management}

Good governance has a positive, but insignificant effect on the quality of asset management for the value of $\alpha=$ $0,220>0,05$ with a coefficient amounting to 0.128 . Thus, the results of the analysis indicate that the sixth hypothesis $\left(\mathrm{H}_{6}\right)$ study was rejected. The coefficient of good governance has a positive mathematical sign. This indicates that the knowledge of good governance which is owned by employees has not been able to improve the quality of asset management. This means that if the knowledge governance increased employee-owned asset, it will encourage the increased quality of asset management. Thus the sixth hypothesis of this study was rejected.

Good governance has not been able to improve the quality of asset management. This means that every director and employee asset manager must have the same view about the importance of good governance in any asset management operation that will create enforcement firm and consistent. Lack of accountability have led to the use of the asset management budget implementation is often misused in a variety of programs and activities that had been budgeted. Moreover on several occasions asset management budget transferred to other programs or activities outside of the pre-planned. This happens because of the lack of accountability in accordance with standard procedures have been established, the weakness of the sanction on any errors or omissions in the implementation of activities and outputs and outcomes implementation of asset management activities have not been measured and appropriate.

As a result of lower asset management accountability they provide no significant effect on the quality of asset management reports. To improve accountability, it is necessary to periodically and systematically responsibility to schedule the use of the asset management budget. The results of this study is different from the statement which states that good governance will realize the achievement of performance results orientation a good asset management area. This meant that the field of asset management needs to be based on the principle of good governance is participatory, responsibility and accountability to produce the work of asset management in accordance with the expected performance (Anderson 2009: 155). The findings of this study rejected the findings of previous investigators that good governance (good governance) positive and significant effect on the quality of financial management reporting information / assets (Holland, 1999; Islam and Dellaportas, 2011).

\section{Linking of civil servants performance on quality asset management}

Civil servants performance has a positive and significant effect on the quality of asset management with a value of $\alpha=0,000>0,05$ and value coefficient of 0,453 . Thus, the results of the analysis indicate that the seventh hypothesis $\left(\mathrm{H}_{7}\right)$ received research. The coefficients of performance of employees have a positive mathematical sign. This shows that the better the performance of employees, the quality of asset management will also increase. Thus the seventh hypothesis of this study is accepted. Civil servants continually improve its performance in the face of the working dynamics that demand improvements in local asset management report. Efforts to avoid the mistake of work to do to improve the reliability, professionalism, experience and want to improve on any shortcomings in carrying out their 
work activities. If the employee is able to minimize work-related errors will result in optimized performance and this affects the performance achievement of the error to the improvement of local asset management report.

Representation of employee performance can be seen on the accuracy of the quality of the asset management area. Accuracy of work can be realized by performing the inspection, observation, editing and comparison of various work related to improving the quality of the asset management area. The results of this study support the statement of the experts that the performance is the result of work on the assessment of quantity, quality, efficiency and effectiveness of the work, the performers are, the more value-added, performance and value-added affect the achievement of the goals of quality management (Benneth, 2008: 68; Aldero, 2009: 27; Alexander, 2009: 71). Supports the findings of some previous researchers, the performances affect on improving the quality of asset management (Ajeng Ratna Purwaningsih, 2015; Yayuk Fitrianti, 2015).

\section{Linking of organizational commitment on quality asset management: The mediating role of civil servants performance}

Organizational commitment has indirect effect on the quality of asset management the mediating role of civil servants performance were positive and significant for $\mathrm{p}$-value $=0,013>0,05$. The indirect effect is having a coefficient of 0,174 and positive. Directly, the influence of this organization's commitment amounted to $-0,012$. Thus the total effect of organizational commitment to quality asset management is $0,162(0,174-0,012)$. This result implies, if the organization's first commitment is directed to improving civil servants performance, and after it is used in asset management, the quality of asset management will also increase. Thus, the results of the analysis show that the hypothesis of the eighth $\left(\mathrm{H}_{8}\right)$ research received.

Improving the quality of asset management can be done directly, even without the help of performance as an intervening variable in explaining the effect of organizational commitment to quality asset management that the performance is not as mediator in explaining the effect of organizational commitment on quality asset management. This means that organizations prioritize people who have the commitment (Luthans, 2005: 64). The commitment is the consistency of what is done. That is to improve the performance; we need people who are consistent in loves his job. Work based on the commitment to love high will produce satisfactory work. Paime (2008: 33) states that the commitments will result in the viewpoint of the achievement of optimal performance.

This perspective becomes important assessment to establish good organizational commitment effectively, normative and continuing to increase a person's performance in the organization. Organizational commitment is positive and significant influence over the performance of employees to quality asset management (Aries Susanti et al., 2013; Purnama, 2013; Sjahruddin and Normijati, 2013).

\section{Linking of competence on quality asset management: The mediating role of civil servants performance}

Competencies has indirect influence on the quality of asset management, the mediating role of civil servants performance were positive and significant for $\mathrm{p}$-value $=0,032<0.05$. The indirect effect is having a coefficient of 0,167 and positive. The effect of competence is 0,352 . Thus the total effect on the quality management assets is $0,519(0,167+0,352)$. This result implies, if the first competence geared to improving civil servants performance, and after it is used in asset management, the quality of asset management will also increase. Thus, the results of the analysis indicate that ninth hypothesis $\left(\mathrm{H}_{9}\right)$ received research.

Competence through civil servants performance has a positive and significant effect on the quality of asset management; these findings support Kreitner and Kinicki (2005) that the competence and quality of the report support the achievement of maximum performance. This means that every organization strives to manage work activities by people who are competent in accordance with motif, nature and knowledge. Employee competences have a positive and significant effect on the quality of work (Stephen William, 2005; Thamrin, 2007; Ajeng Ratna Purwaningsih, 2015).

Linking of good governance on quality asset management: The mediating role of civil servants performance Good governance has indirect effect on the quality of asset management, the mediating role of civil servants performance were positive and insignificant because the $\mathrm{p}$-value $=0,065>0,05$. The indirect effect is having a coefficient of 0,102 and positive. The effect of good governance is 0,128 . Thus the total effect of good governance on the quality asset management is $0,230(0,128+0,102)$. This result implies, if the first governance geared to 
improving civil servants performance, and after it is used in asset management, the quality of asset management will also increase. Thus, the results of the analysis show that the hypothesis to ten $\left(\mathrm{H}_{10}\right)$ study was rejected.

The effect of good governance on the quality of asset management, the mediating role of civil servants performance backed support statement Salton (2006) that the basic principle of governance is the order in formulating any implementation that can be evaluated according to the program's objectives and activities. Principles of good arrangement must involve participation, transparency, responsibility, accountability, consensus, efficiency and effective (Adolf, 2008).

Planning activities must involve many people, conducted in an open way, full responsibility in accepting and completing tasks given authority over, accountability in implementation of activities, involving a collective agreement, efficient and effective use of time and use of the budget. Then the study's findings rejected the findings of previous investigators that good governance positive and significant effect on the quality of financial management reporting information / assets (Holland, 1999; Islam and Dellaportas, 2011).

\section{Conclusions and Recommendations}

Organizational commitment has a positive and significant effect on civil servants performance. The results of this study mean, the high the organization's commitment owned by a civil servants, the civil servants performance will also increase. Competence has a positive and significant effect on civil servants performance. It shows that the better the competency of asset management, then the civil servants performance will increase.

Good governance has a positive and significant effect on civil servants performance. This shows that the better knowledge of good governance owned asset management staff, the more it will improve the civil servants performance. Organizational commitment has a negative effect is insignificant on quality of asset management. This means that organizational commitment does not significantly effect on the quality of asset management. The coefficient of direct influence is marked with a negative mathematical. This means that the higher organizational commitment owned by civil servants, tends to degrade the quality of asset management in the study. This means, organizational commitment does not directly improve the quality of asset management.

Competence has a positive and significant impact on the quality of asset management. This shows that the better the competency of employees, the quality of asset management, the better. Good governance has a positive, but insignificant effect on the quality of asset management. This indicates that the knowledge of good governance which is owned by employees has not been able to improve the quality of asset management. This means that if the knowledge governance increased employee-owned asset, it will encourage the increased quality of asset management.

Civil servants performance has a positive and significant effect on the quality of asset management. This shows that the better the civil servants performance, the quality of asset management will also increase. Organizational commitment has indirect influence on the quality of asset management, the mediating role of civil servants performance were positive and significant. This result implies, if the organizational commitment is directed to improving civil servants performance, and after it is used in asset management, the quality of asset management will also increase.

Competence has indirect influence on the quality of asset management, the mediating role of civil servants performance were positive and significant. This result implies, if the first competence geared to improving civil servants performance, and after it is used in asset management, the quality of asset management will also increase. Good governance has indirect influence on the quality of asset management, the mediating role of civil servants performance were positive and insignificant. This result implies, if the good governance geared to improving civil servants performance, and after it is used in asset management, the quality of asset management will also increase.

It takes the seriousness of the Government of Makassar to increasingly pay attention to the characteristics of employees, so the orientation of the personnel management of the management of administrative adapt to the management of human resources in terms of necessary planning of civil servants according to the workload and the need for implementing asset management, demand planning education and educational and optimizing the use of technology and computerized data processing in order to accelerate the region's assets. Civil servants competency asset managers need to be maintained and enhanced in asset management in order to achieve the work in the field 
over the maximum asset, by providing training opportunities and the like, especially relating to asset management to every employee asset manager.

Good governance should be implemented in accordance with the principles of openness, fairness and accountability in order to produce the information asset management reporting. Subsequent research authors recommend adding variables internal control system as a factor affecting the quality of the asset management area. This variable is very important to analyze the performance of employees to report asset management apply the components of internal control of every operating activity from planning, implementation, monitoring up to liability in an orderly, controlled and efficient and effective so that they can produce information reports in the relevant asset, reliable, comparable and easily understood.

\section{References}

1. Adolf, Berk, (2008). Auditing and Management. Routledge and Kegan Paul, London.

2. Ajeng Ratna Purwaningsih, (2015). The Influence of Competence, Independence, Due Professional Care, And Motivation to Quality Audit - Empirical Study at Provincial / Regency / City Inspectorate of Lombok Island. UNRAM Post Graduate Program, NTB.

3. Alamsyah M. Tahir, (2012). Influence of Human Resource Capacity, Information Technology, Organizational Commitment and Organizational Culture on Quality Audit (Study on Inspectorate of Mataram City). UNRAM Graduate Program. NTB.

4. Aldero, James, (2009). The Human Resource People Strategy and Performance. Harvard Business School Press. Boston.

5. Alexander. Nelly, (2009). Human Resource Management in Strength Quality Prospective. Published McGraw Hill, New York.

6. Allen, S., and Meyer, G., (2009). Organization Commitment in Management Perspective. Published by Prentice Hall, New York.

7. Anderson, Robert A.G, (2009). Corporate Governance. 3rd Edition, Blackwell Publishing.

8. Aries Susanty, Sigit Wahyu Baskoro. 2012. The Influence Of Work Motivation And Style Leadership To Discipline Work and its impact on Performance Employee (case study at PT PLN (Persero) APD semarang) Journal J @ TI Undip, Vol VII, No. 2, May 2012

9. Arthur, Harold A, (2006). Essentials of Organization Culturing. Fifth Edition, McGraw Hill, Inc., Singapore.

10. Azis Rachman (2012) under the title Influence of Leadership Types, Competencies, Work Facilities and Motivation to Work Moral and Lecturer Work Quality at Private Universities in Gorontalo Province

11. Barry, James F,. (2011). Internal Auditor Behavior. London: ELBS and MacDonald and Evans

12. Benneth, Lays, (2008). Human Resource Management, Published by McGraw Hill. Ohio.

13. Cohen, Marvin, (2010). Auditing and Accounting. Published by Prentice Hall, New York.

14. Dardton, Fred. R, (2009). A Blueprint for Corporate Governance: Strategy, Accountability, and the Preservation of Shareholder Value, AMACOM, USA

15. Fifien Dhesta Listiyana, (2015). Influence of Leadership Style, Discipline, Organizational Culture, Motivation and Organizational Commitment to Performance of Regional Finance Manager (Study on Revenue Service, Financial Management and Regional Asset of Wonogiri Regency). Faculty of Economics, University of Muhammadiyah Surakarta

16. Finger, M., \& Pécoud, G. (2003). From e-Government to e-Governance? Towards a model of eGovernance. In Proceedings of the 3rd European Conference on E-Government-ECEG (No. MIRARTICLE-2005-061, pp. 119-130).

17. Gimbart, John D., (2008). Behavior Principles in Organization Everyday Life. 2nd ed. Englewood Cliffs, Prentice Hall, New Jersey

18. Goeslow Vanila (2005). dengan judul: Affect of Culture, Competence, Moral and Quality by Human Resource toward Performance in Investment Company Florida.

19. Harijaya, Shadik, (2004). Self Development towards Optimal Competence. Publisher Harvarindo, Jakarta.

20. Hasfi, N., \& Martoyo, D. H. (2013). Management of Regional Property (A Study on Revenue Service, Financial Management and Sintang District Assets). Master of Social Sciences Faculty of Social and Political Sciences, University of Tanjungpura Pontianak. Journal of PMIS UNTAN PSIAN Thesis, 1 (0001).

21. Holland, John, (1999). Financial Reporting, Private Disclosure and Corporate Role Institutions. Journal of Management \& Governance, 1999, 3, 3, Proquest Health Management, pg, 161. 
22. Houston, W. Robert; Howsam, Robert B., (1972), Competency Based Teacher Education. Progress. Problem and Prospects, Science Research Associates Inc., Sydney

23. Ibrahim, (2008). Management and Performance. Publisher Rineka Cipta, Jakarta.

24. Islam, M., \& Dellaportas, S. (2011). Perceptions of corporate social and environmental accounting and reporting practices from accountants in Bangladesh. Social responsibility journal, 7(4), 649-664.

25. John Gamara Tangke, Halim and Tangke. (2015). Effect of Optimization of Regional Asset Management on Quality of Financial Statements of Makassar City Government. Journal of the State Administration Vol. 21 No. April 1, 2015.

26. Kreitner, R. \& Kinicki, A. (2005) Organizational Behavior, Jakarta:Salemba Empat.

27. Luthans, Fred, (2007). Organizational Behavior. New York, McGraw-Hill Book Company, $3^{\text {rd }}$, edt.

28. Luthans, Herbergson, (2005). Theory of Motivation in Human Resource Management. http://www.journalmotivation.com.id.

29. Mangkunegara, Anwar Prabu. (2000). Human Resource Management. Company. Bandung: PT Remaja Rosdakarya.

30. Martin, Jones, (2002). "Auditing and financial of company", Published by John Wiley and Sons, New York.

31. Maturidi, (2014). The Influence Of Competence And Independence Of Internal Supervisory Unit And Implementation Of Good Corporate Governance To The Performance Of BPR In Lombok Island. Journal of GaneÇ Swara Vol. 8 September 2nd, 2014

32. Meynalti Handhayani, (2015). Effect of Work Quality and Organizational Commitment on Employee Performance Secretariat of Solok City Council, Jurnal Fakultas Ekonomi Universitas Taman Siswa Padang

33. Natalia Dewinda Putri, (2010). The Effect of Organizational Commitment and Role of Regional Financial Management Manager to Managerial Performance of Regional Device Work Unit, Faculty of Economics, Diponegoro University, Semarang

34. Nur Azlina and Ira Amelia, 2014. The Influence of Good Governance and Internal Control to Pelalawan Regency Government Performance. Jember Accounting Journal - Vol. 12 No. 2 Dec 2014

35. Nurul Azizah, (2012). The Influence of Organizational Commitment, Role of Manager, and Participation of Regional Budgeting Compilation on Managerial Performance (Case Study In Sukoharjo District Dppkad). Faculty of Economics, University of Muhammadiyah Surakarta

36. Organisation for Economic Co-operation and Development (2010), OECD Feasibility Study for the International Assessment of Higher Education Learning Outcomes, OECD publishing,

37. Paime, Dhurman, (2008). Human Resource Management. West Publishing Company, New York.

38. Pekei, B., Hadiwidjojo, D., \& Djumahir, S. (2014). The Effectiveness Of Local Asset Management (A Study On The Government Of Jayapura). International J Business and Management Invention, 3(3), 16-26.

39. Purnama, C. (2013). Influence Analysis of Organizational Culture Organizational Commitment Job and Satisfaction Organizational Citizenship Behavior (OCB) Toward Improved Organizational Performance. International journal of business, humanities and technology, 3(5), 86-100.

40. Rahmawati Halim, (2012). The Influence of Organizational Commitment and Leadership Role in Improving Regional Financial Management at Revenue Service, Financial Management and Asset of Banggai Regency Journal Academica Islands Fisip UNTAD Vol. 04 No. 01 February 2012.

41. Rhodes, R.A.W. (1997) Understanding governance: policy networks, governance, reflexivity and accountability, Philadelphia, US, Open University Press, 252pp. (Public Policy \&amp; Management).

42. Rivai, Veithzal (2007). Human Resources management in Theory and Practice. PT. RajaGrafindo Persada, Jakarta.

43. Salton, Robin, (2006). Corporate Governance, Journal of Law and Economics, (Vol. 48, October), 371

44. Santoso, D. (2008). Failure to Implement Good Corporate Governance in Public Companies In Indonesia. Journal of Law IUS QUIA IUSTUM, 15 (2).

45. Schemerhorn, French, Hunt, Briant, and Osborn, 2007. Human Resource in Performance Management. $2^{\text {nd }}$ Edition, Mas Hougton Mifflin Company, Boston

46. Siagian, P. Sondang, (2004). Organizational Management. Jakarta: PT. Reader Binaman Pressindo.

47. Siregar, Doli.D. (2004). Asset Management, Jakarta: Satyatama Graha Tara

48. Sjahruddin, H., \& Normijati, A. A. S. (2013). Personality effect on organizational citizenship behavior (OCB): trust in manager and organizational commitment mediator of organizational justice in Makassar City Hospitals (Indonesia). European Journal of Business and Management, 5(9), 95-104.

49. Spencer and Spencer, (1993). The Principle of Good Governance. Prentice Hall International, New York 
50. Sri Trisnaningsih. (2007). Auditor Independence And Organizational Commitment As Mediation Influence Of Understanding Good Governance, Leadership Style And Organizational Culture To Auditor Performance. Data and Business Center FEB UI. Jakarta

51. Stephen William (2005) The Competence, Motivation and Morality toward Performance and Increasing The Quality of Staff in Australia College".

52. Stoner, B and Freedman., (2000). Essentials of Organizational Behavior: Management Research. Prentice Hall International Inc, New Jersey

53. Sugiama, A Gima (2013), Tourism Asset Management, Guardaya Intimarta, Bandung

54. Surhatiningsih, (2008). The influence of organizational culture, work morale, Competence to Improving the Quality of work and performance of West Java Provincial Government Employees.

55. Syahruni Sukri, (2015). Effect of Asset Inventory, Quality of Human Resources and Leadership Commitment to Optimization of Asset Management and Quality of Local Government Financial Report of Takalar Regency. Journal Publisher.

56. Thamrin, (2007). The Influence of Competence, Work Moral and Organizational Culture on Quality of Work and Performance at Provincial Government of South Sulawesi.

57. Walker, Domascus, (2007). Organizational Behavior in Characteristic Qualified. Prentice Hall Cliffs, New Jersey.

58. Wibowo. (2007). Performance Management. PT. Raja Grafindo Parsada: Jakarta.

59. Yayuk Fitrianti, (2015). The Influence of Accountability, Independence and Compliance on the Code of Ethics on Audit Quality (Empirical Study of Regency / City Inspectorate Officials on Sumbawa Island of NTB Province). Post Graduate Program, UNRAM, NTB

60. Yoseph, (2009). Culture, Moral and Competence as Predictor toward Increasing the Performance and Quality by Human Resource Change in a Non-Westem Setting. 